\title{
STUDI KASUS PADA PASIEN DENGAN HIPERTENSI MELALUI PENERAPAN REBUSAN DAUN SAMBUNG NYAWA
}

\author{
${ }^{1}$ Isna Aglusi Badri \\ ${ }^{2}$ Kezia Visillia Saikoko \\ Institut Kesehatan Mitra Bunda \\ (isna_loushe@yahoo.co.id)
}

\begin{abstract}
ABSTRAK
Hipertensi merupakan penyebab kematian nomor 1 dan merupakan penyebab kematian terbesar nomor 3 di Indonesia dengan persentasi sebesar 6,7\% setelah stroke dan penyakit jantung. Tujuan dari penelitian ini adalah memberi gambaran asuhan keperawatan yang komprehensif terhadap lansia kelolaan dengan hipertensi. Metode yang digunakan adalah studi kasus yang dilakukan berdasarkan tahap-tahap asuhan keperawatan meliputi pengkajian, diagnosa, intervensi, implementasi, dan evaluasi keperawatan. Hasil pengkajian didapatkan lansia mengeluh, kepala sakit, tengkuk tegang, klien tampak pucat, kulit teraba dingin, sehingga diagnosa keperawatan yang muncul yaitu perfusi perifer tidak efektif berhubungan dengan hipertensi, klien mengeluh nyeri kepala, nyeri menyebar sampai ketengkuk, nyeri hilang timbul didapatkan skala nyeri 5 diagnosa yang muncul yaitu nyeri akut berhubungan dengan peningkatan tekanan vaskuler serebral, dan klien mengeluh kakinya kebas, tidak kuat berdiri terlalu lama dan berjalan jauh, pernah jatuh \pm 3 bulan yang lalu diagnosa yang muncul yaitu resiko jatuh berhubungan dengan riwayat jatuh, neuropati. Akhir pemberian asuhan keperawatan dengan pemberian air rebusan daun sambung nyawa (gynura procumbens) sebanyak 1 hari sekali $(150 \mathrm{ml})$ pada siang hari selama 7 hari dapat menurunkan tekanan darah pada lansia yang mengalami hipertensi sehingga dapat digunakan sebagai alternatif pengobatan non farmakologi yang tidak memiliki efek samping yang merugikan, serta mudah didapatkan. Saran bagi lansia yang memiliki hipertensi agar dapat menerapkan air rebusan daun sambung nyawa (gynura procumbens) dirumah karena mudah untuk dilakukan sendiri.
\end{abstract}

\section{Kata kunci : Hipertensi ; Daun Sambung Nyawa}

\begin{abstract}
Hypertension is the number 1 cause of death in the world and the third largest cause of death in Indonesia with a percentage of $6.7 \%$ after stroke and heart disease. The purpose of this scientific paper is to provide a comprehensive overview of nursing care for elderly people managed with hypertension. The method used in papers is a case study based on the stages of nursing care including assessment, diagnosis, intervention, implementation and evaluation of nursing. The results of the study showed that the elderly complained, the head hurt, the neck was tense, the client looked pale, the skin felt cold, so that the nursing diagnosis that appeared was ineffective peripheral perfusion associated with hypertension, the client complained of headaches, pain spreads to the neck, the pain disappeared and arose a pain scale. 5 diagnoses that emerged were acute pain associated with increased cerebral vascular pressure, and the client complained of numb legs, not being able to stand too long and walking long distances, having fallen \pm 3 months ago the diagnosis that appeared was the risk of falling associated with a history of falls, neuropathy. The end of providing nursing care by providing boiled water of gynura procumbens once a day $(150 \mathrm{ml})$ during the day for 7 days can reduce blood pressure in elderly people with hypertension so that it can be used as an alternative non-pharmacological treatment that has no effect. side that is detrimental, and easy to get. Suggestions for the elderly who have hypertension can apply boiled water of gynura procumbens at home because it is easy to do by yourself.
\end{abstract}

Key words: Hypertension ; Boiled water of gynura procumbens 


\section{PENDAHULUAN}

Lansia atau menua adalah suatu keadaan yang terjadi di dalam kehidupan manusia. Menjadi tua merupakan proses alamiah, yang berarti seseorang telah melalui tiga tahap kehidupannya, yaitu anak, dewasa dan tua. Memasuki usia tua lansia mengalami perubahan baik secara biologis maupun psikologis. Perubahan biologis ditandai dengan kulit yang mengendur, rambut memutih, gigi mulai ompong, pendengaran kurang jelas, penglihatan semakin memburuk, gerakan lambat dan figur tubuh yang tidak proporsional, dan penurunan fungsi organ, sedangkan perubahan psikologis ditandai dengan lansia lebih mudah merasa cemas, stress, depresi dan paranoid (Nasrullah, 2016).

Terjadinya perubahan biologis dan psikologis pada lansia akibat proses penuaan menyebabkan lansia rentan terkena penyakit salah satunya Hipertensi. Hipertensi merupakan penyebab kematian nomor 1 di dunia dan Hipertensi merupakan penyebab kematian terbesar nomor 3 di Indonesia dengan presentasi sebesar 6,7\% setelah stroke dan penyakit jantung (Kemenkes RI, 2019). Hipertensi juga merupakan penyakit nomor 1 yang sering terjadi pada lansia di Indonesia disusul dengan penyakit Artritis, Stroke, Penyakit Paru Obstruktif Kronik (PPOK), Diabetes Melitus (DM), Kanker, Penyakit Jantung Coroner, Batu Ginjal, Gagal Jantung, dan Gagal ginjal (Infodatin, 2016). Hipertensi pada kelompok usia lanjut disebabkan karena adanya perubahan konsistensi pembuluh darah arteri sehingga elastisitas dinding pembuluh darah menurun dan menjadi kaku (Lionakis, 2012). Hal ini juga dipaparkan oleh studi lain bahwa penyebab hipertensi pada lanjut usia yaitu katup jantung yang menebal dan kaku, elastisitas dinding aorta yang menurun, curah jantung menurun, kinerja jantung lebih rentan terhadap pendarahan sehingga terjadi peningkatan tekanan darah (Kenia, 2013). Ciri khas hipertensi pada lanjut usia yaitu tekanan darah sistolik yang mengalami peningkatan hingga diatas $140 \mathrm{mmHg}$ sedangkan tekanan darah diastolik tetap normal yaitu dibawah $90 \mathrm{mmHg}$. Jenis hipertensi seperti ini disebut Isolated Systolic Hypertension (ISH) atau hipertensi sistolik terisolasi (Seke, 2016). Hipertensi jika di biarkan dalam jangka waktu panjang akan menimbulkan beberapa penyakit degeneratif seperti stroke, aterosklerosis, hingga kematian (Fathimah, 2019).

Proporsi lansia di Indonesia diperkirakan dua kali lipat dari $12 \%$ sampai $22 \%$ antara 20152050. Hal ini merupakan peningkatan yang tidak dapat diduga dari 900 jiwa menjadi 2 milyar orang dengan usia 60 tahun, terdapat 125 juta orang dengan usia 80 tahun bahkan lebih (Kemenkes RI, 2017).

Badan Pusat Statistik kepulauan Riau tahun 2016 mencatat bahwa penduduk berusia lanjut adalah sebanyak 200.922 jiwa dan Jumlah penduduk lansia kota Batam 2017 adalah sebanyak 46.686 jiwa (Profil Dinas Kesehatan Kota Batam, 2017).

Data World Health Organization (WHO) tahun 2015 menunjukkan sekitar 1,13 Miliar orang di dunia menderita hipertensi, artinya 1 dari 3 orang di dunia terdiagnosis hipertensi. Jumlah penyandang hipertensi terus meningkat setiap tahunnya, diperkirakan pada tahun 2025 akan ada 1,5 Miliar orang yang terkena hipertensi, dan diperkirakan setiap tahunnya 9,4 juta orang meninggal akibat hipertensi dan komplikasinya (Fitri, 2020). Menurut WHO tahun 2013, 45\% kematian karena penyakit jantung disebabkan oleh hipertensi, begitu pula dengan kematian karena stroke mencapai 51\% ( Fathimah, 2019).

Data Riset Kesehatan Dasar tahun 2018 menunjukkan bahwa terjadi peningkatan prevalensi hipertensi dari 31,7\% tahun 2007 menjadi sebesar 34,1 \% tahun 2018 (Riskesdas, 2018). Data Sample Registration Survey tahun 2014 menunjukkan bahwa 
hipertensi merupakan penyebab kematian terbesar nomor 3 di Indonesia dengan presentasi sebesar $6,7 \%$ setelah stroke dan penyakit jantung ( Parwati, 2018).

Data Riset Kesehatan Dasar Kepri menunjukkan prevalensi Hipertensi tertinggi terdapat di Batam yaitu sebesar 4.587 jiwa (Riskesdas Kepri, 2018). Berdasarkan data dari Dinas Kesehatan pada tahun 2019 didapatkan prevalensi penyakit tertinggi di Batam yaitu Hipertensi dengan total 70.122 jiwa dan kejadian Hipertensi tertinggi terdapat di Puskesmas Sei. Langkai yaitu sebanyak 13.682 jiwa (Dinkes, 2019).

Penelitian yang dilakukan oleh Irmaya Sari (2019) dengan judul Pengaruh Pemberian Air Rebusan Daun Sambung Nyawa (Gynura Procumbens) Terhadap Tekanan Darah Pada Lansia Di Puskesmas Lubuk Jambi, didapatkan hasil penelitian dari 16 responden diberikan air rebusan daun sambung nyawa (gynura procumbens) 1 kali sehari diwaktu siang hari sebanyak $150 \mathrm{cc}$ selama 7. Hal ini membuktikan bahwa ada pengaruh yang bermakna dari pemberian air rebusan daun sambung nyawa (gynura procumbens) terhadap penurunan tekanan darah pada penderita hipertensi.

Hipertensi dapat dicegah dengan mengendalikan perilaku berisiko seperti merokok, diet yang tidak sehat seperti kurang konsumsi sayur dan buah serta konsumsi gula, garam dan lemak berlebih, obesitas, kurang aktifitas fisik, konsumsi alkohol berlebihan dan stres. Upaya yang telah dilakukan pemerintah dalam pencegahan dan pengendalian Hipertensi diantaranya adalah meningkatkan promosi kesehatan melalui KIE (Komunikasi, Informasi dan Edukasi) dalam pengendalian Hipertensi dengan perilaku CERDIK dan PATUH yaitu dengan meningkatkan pencegahan dan pengendalian Hipertensi berbasis masyarakat dengan Self Awareness melalui pengukuran tekanan darah secara rutin, penguatan pelayanan kesehatan khususnya Hipertensi. Pemerintah juga telah melakukan berbagai upaya seperti meningkatkan akses ke Fasilitas Kesehatan Tingkat Pertama (FKTP), optimalisasi sistem rujukan, dan peningkatan mutu pelayanan. Salah satu upaya pencegahan komplikasi Hipertensi khususnya Penyakit Jantung dan Pembuluh Darah di FKTP melalui Pelayanan Terpadu (PANDU) Penyakit Tidak Menular (PTM), Pemberdayaan masyarakat dalam deteksi dini dan monitoring faktor risiko hipertensi melalui Posbindu PTM yang diselenggarakan di masyarakat, di tempat kerja dan institusi (Kemenkes RI, 2019).

Ada dua macam terapi yang bisa dilakukan untuk mengobati penyakit hipertensi, yaitu terapi farmakologi dengan menggunakan obat dan terapi nonfarmakologi. Terapi farmakologi yang digunakan ialah diuretic, beta blocker, calcium channel blocker atau calcium antagonist, angiotensin converting enzyme inhibitor dan angiotensin II receptor blocker. Pengobatan farmakologis memiliki efek yang lebih cepat dibandingkan dengan pengobatan nonfarmakologis. Tetapi pengobatan farmakologis memiliki efek samping yang lebih besar dibandingkan pengobatan nonfarmakologis. Salah satu efek samping yang ditimbulkan oleh salah satu obat anti hipertensi yaitu golongan diuresis akan mengakibatkan peningkatan jumlah air seni, dan disfungsi ereksi. Efek samping yang terjadi terus menerus dapat menyebabkan penyakit serius dan dapat berakhir pada kematian (Fitri, 2020).

Melakukan asuhan keperawatan pada klien dengan masalah Hipertensi penulis dapat menerapkan asuhan keperawatan secara komprehensif dan sesuai standar asuhan keperawatan dan terjadi penurunan tekanan darah dengan diterapkannya terapi pemberian air rebusan daun sambung nyawa (Gynura Procumbens) pada klien dengan Hipertensi di Wilayah Kerja Puskesmas Sei. Panas Kota Batam Tahun 2020.

\section{METODE PENELITIAN}


Metode yang digunakan adalah deskriptif analitik dengan studi kasus yang mana yang menjadi subjek study adalah lansia yang mengalami Hipertensi. Teknik dalam penggumpulan data adalah wawancara, observasi dan Studi dokumentasi. Alat yang digunakan dalam mengumpulkan data adalah format pengkajian dan alat - alat untuk melakukan pengkajian. Penelitian ini dilakukan di Wilayah Kerja Puskesmas Sei panas pada bulan Oktober 2020.

\section{HASIL DAN PEMBAHASAN}

Hasil pengkajian didapatkan pasien mengatakan kepalanya sering sakit, tengkuknya terasa tegang, klien mengatakan nyeri kepala semakin terasa saat klien beraktivitas, klien juga mengatakan pernah jatuh \pm 3 bulan yang lalu, kaki terasa kebas, tidak kuat berdiri terlalu lama karna sakit kepala dan kakinya yang terasa kebas, klien mengatakan hanya menggunakan minyak angin untuk meredakan sakit kepala dan tengkuknya yang terasa tegang, klien tidak mengkonsumsi obat hipertensi. Didapatkan tanda-tanda vital klien: TD: 160/110 mmHg,N: 90x/I, S: 36, $2^{\circ} \mathrm{C}$, RR: 22x/I, hasil pengkajian nyeri $\mathrm{P}$ (provocate): klien mengatakan nyeri saat klien mulai beraktivitas, Q (quality): nyeri seperti mencengkam, $\mathrm{R}$ (region): nyeri kepala menjalar ke tengkuk, S (scale)skala nyeri 5, $\mathrm{T}$ (time): nyeri hilang timbul durasi \pm 10 menit, kulit teraba dingin, wajah klien tampak pucat.

Berdasarkan hasil pengkajian pada pasien dengan kasus Hipertensi telah sesuai dengan teori yang ditemukan oleh penulis.Hipertensi adalah tekanan darah persistem dengan tekanan sistolik di atas $140 \mathrm{mmHg}$ dan tekanan darah diastolik di atas 90 mmHg.Keluhan yang disampaikan oleh pasien sesuai dengan tanda dan gejala hipertensi menurut Smeltzer (2010), yaitu sakit kepala, rasa tidak nyaman pada daerah tengkuk,.Penderita hipertensi sering merasa nyeri kepala. Gejala umum yang ditimbulkan akibat menderita hipertensi tidak sama pada setiap orang, bahkan timbul tanpa gejala. Secara umum gejala yang dikeluhkan oleh penderita hipertensi meliputi: rasa lelah, sakit kepala dan telinga berdenging, rasa pegal dan tidak nyaman pada tengkuk, detak jantung terasa cepat, serta perasaan berputar seperti tujuh keliling.

Berdasarkan pengkajian yang dilakukan oleh Jordy (2019) dengan judul Asuhan Keperawatan gerontik pada lansia Tn.P.L dengan Hipertensi di Ruang Komodo RSUD. PROF. DR. W.Z, Johannes Kupang, keluhan klien mengatakan pusing, tegang leher, nyeri lutut, dan sering merasakan nyeri dada apabila malakukan aktivitas terlalu berat. Hasil pemeriksaan tanda-tanda vital diperoleh tekanan darah 180/100 $\mathrm{mmHg}$, frekuensi pernapasan $20 \mathrm{x} /$ menit, frekuensi nadi $65 \mathrm{x} / \mathrm{menit}$, suhu $36^{\circ} \mathrm{C}$.

Keluhan yang disampaikan oleh pasie sesuai dengan teori menurut Ardiansyah (2012) dimana gejala yang dialami klien dengan kasus hipertensi antara lain sakit kepala (rasa berat di tengkuk), palpitasi, kelelahan, nausea, kegugupan, keringat berlebihan, pucat, kulit teraba dingin, tremor otot, pandangan kabur, kaki kesemutan, neuropati.

Dari hasil pengkajian maka diagnose yang dimuncul adalah Perfusi perifer tidak efektif berhubungan dengan hipertensi, nyeri akut berhubungan dengan peningkatan tekanan vaskuler serebral dan resiko jatuh berhubungan dengan neuropati.

Dalam melakukan implementasi terhadap pasien penulis berpedoman pada intervensi yang telah disusun sesuai dengan intervensi yang telah direncanakan, yaitu setelah dilakukan kunjungan sebanyak 7 kali selama 1x60 menit pada pasien, Implementasi yang dilakukan untuk diagnosa perfusi perifer tidak efektif berhubungan dengan hipertensi yaitu: Mengucapkan salam, memvalidasi keadaan klien, membuat kontrak, menjelaskan tujuan kunjungan, membina 
hubungan saling percaya, memeriksa sirkulasi perifer (mis. nadi perifer, edema, pengisian kapiler, warna, suhu, ankle brachial index), mengidentifikasi faktor resiko gangguan sirkulasi (mis. diabetes, perokok, orang tua, hipertensi dan kadar kolestrol tinggi), memonitor panas, kemerahan, nyeri, atau bengkak pada ekstremitas, menganjurkan berolahraga rutin, menganjurkan pemberian terapi nonfarmakologi untuk menurunkan tekanan darah: pemberian air rebusan daun sambung nyawa (Gynura procumbens), menganjurkan melakukan perawatan kulit yang tepat (mis.melembabkan kulit kering pada kaki), mengajarkan program diet untuk memperbaiki sirkulasi(mis.rendah lemak jenuh, minyak ikan omega 3).

Menurut teori Sudarsono, et al (2006), Daun sambung nyawa merupakan salah satu dari jenis terapi herbal untuk menangani penyakit hipertensi. Daun Sambung Nyawa mengandung flavonoid (7,3,4 trihidroksiflavon), glokosida, kuersetin, asam fenoleat (terdiri dari asam kafeat, asam P-kumarat, asam P-hidroksi benzoat, asam vanilat), triterpenoid, saponi, steroid, dan minyak atsiri.Kandungan zat aktif yang dominan dari daun sambung nyawa adalah flavonoid yang bekerja denganmeningkatkan konsentrasi serum NO (Nitrite Oxide). NO merupakan molekul kecil yang berfungsi sebagai vasodilator dan menyebabkan tekanan darah menurun. Dengan demikian rebusan daun sambung nyawa memiliki peranan mekanisme terhadap penurunan tekanan darah.

Hal ini sesuai denganpenelitian yang dilakukanoleh Irmaya Sari (2019) dengan judul "Pengaruh Pemberian Air Rebusan Daun Sambung Nyawa (gynura procumbens) Terhadap Tekanan Darah Pada Lansia Yang Mengalami Hipertensi", Berdasarkan jenis penelitian quasy experiment yang dilakukan dengan 16 responden didapatkan hasil uji statistik pada penelitiannya yaitu $(\mathrm{p}=0,000<$ $\alpha=0,05)$, artinya ada pengaruh yang bermakna dari pemberian air rebusan daun sambung nyawa terhadap penurunan tekanan darah pada penderita hipertensi sesudah diberikan air rebusan daun sambung nyawa yaitu setelah 7 hari perlakuan.

Begitu juga penelitian yang dilakukan oleh Nur Syaroh (2019) dengan judul "Pengaruh Rebusan Daun Sambung Nyawa (Gynura Procumbens) Terhadap Tekanan Darah Pada Lansia Hipertensi Di Desa Borobudur Tahun 2019", menyatakan bahwa terdapat pengaruh rebusan daun sambung nyawa terhadap tekanan darah pada lansia hipertensi, yang dilakukan dengan rancangan penelitian yang digunakan yaitu quasy eksperiment. Sampel yang digunakan berjumlah 44 responden, uji Independent T-Test menunjukkan perbedaan pengaruh pemberian rebusan daun sambung nyawa (Gynura Procumbens) terhadap tekanan darah sistole dan diastol dengan nilai $\alpha<0,05(p=0,000$ dan $p=0,041)$.

Setelah dilakukan tindakan selama 7 hari kunjungan, klien pertama kali diberikan air rebusan daun sambung nyawa, klien mengatakan sudah menderita hipertensi sejak \pm 2 tahun lalu dan jarang memeriksakan tekanan darahnya ke pelayanan kesehatan, klien mengatakan kepala sakit dan tengkuk terasa tegang, klien mengatakan masih sering mengkonsumsi makanan berlemak, berminyak, dan tinggi garam, klien mengatakan mengerti cara pengelolaan hipertensi dengan mengatur pola makan dan melakukan olahraga, klien mengatakan mau menerapakan konsumsi air rebusan daun sambung nyawa, wajah tampak pucat, kulit teraba dingin, TD: $160 / 110 \mathrm{mmHg}$.

Pada hari ke tujuh penerapan konsumsi air rebusan dun sambung nyawa, klien mengatatan badannya sudah terasa fit dan segar, klien mengatakan sudah tidak merasakan sakit kepala dan tegang pada tengkuknya, klien mengatakan sudah tidak mengkonsumsi makanan berlemak, berminyak dan tinggi garam, klien mengatakan sudah bisa berolahraga seperti 
biasanya, klien mengatakan mampu melakukan pengelolaan hipertensi dengan berolahraga dan menjaga pola makan, klien mengatakan mampu menerapkan cara menurunkan darah dengan air rebusan daun sambung nyawa secara mandiri dirumah kesadaran composmentis, kulit kepala teraba hangat, klien tampak segar dan bertenaga, klien tampak sudah tidak memegangi kepala dan tengkuknya.

Untuk masalah nyeri akut hari ketujuh klien mengatakan sudah tidak merasakan nyeri pada kepala, tengkuknya sudah tidak terasa tegang lagi, klien mengatakan mampu melakukan terapi relaksasi nafas dalam yang diajarkan secara mandiri, sudah dapat melakukan aktifitas seperti biasa.

\section{KESIMPULAN}

Setelah dilakukan asuhan keperawatan selama 7 kali pertemuan dengan terapi pemberian rebusan daun sambung nyawa tekanan darah pada klien mulai menurun perlahan, klien juga tidak merasakan sakit kepala dan tegang pada tengkuk. Klien mampu melakukan pengelolaan hipertensi dengan olah raga dan menghindari makanan berlemak, berminyak dan, tinggi garam, kulit klien teraba hangat, tanda-tanda vital dalam batas normal TD: 140/80 $\mathrm{mmHg}, \mathrm{N}$ : 84x/I, RR: $20 x / \mathrm{I}, \mathrm{S}: 36,4^{\circ} \mathrm{C}$, masalah perfusi perifer tidak efektif klien teratasi, intervensi dihentikan. Pada diagnosa keperawatan kedua nyeri akut berhubungan dengan peningkatan tekanan darah vaskuler serebral.

\section{UCAPAN TERIMA KASIH}

Dalam kesempatan ini penulis mengucapkan terima kasih kepada segala pihak yang telah banyak membantu diantaranya :
1. Ibu Hj Gusnawati, STR, M Keb selaku Ketua Yayasan Harapan Bunda Batam.

2. Bapak dr. H. Mawardi Badar, MM selaku rekor Institut Kesehatan Mitra Bunda yang telah memberikan dukungan untuk melakukan penelitian.

3. Wakil Rektor I, II dan III yang telah memberikan dukungan untuk melakukan penelitian.

4. Puskesmas Sei Panas yang telah memberi izin melakukan penelitian.

5. Pasien yang telah bersedia menjadi responden dalam penelitian ini.

\section{REFERENSI}

Adib. M. 2009. Cara Mudah Memahami dan Menghindari Hipertensi Jantung dan stroke. Yoyakarta: Dianloka Pustaka

Azizah., 2011, keperawatan lanjut usia, Graha Ilmu, Yogyakarta.

Badan Pusat Statistik. 2012. Data Lansia Didunia. http://www.Depkes.go.id. diakses tanggal 3 Juli 2018.

Buckman \& Wescott, 2010. Apa yang Anda Ketahui tentang Tekanan Darah Tinggi. Klaten .PT intan sejati

Buku Ajar Keperawatan Kardiovaskuler. Jakarta : Bidang Pendidikan dan Latihan Pusat Kesehatan Jantung dan Pembuluh Darah Nasional "Harapan Kita".

Dewi dan Familia, 2010. Hidup Bahagia dengan Hipertensi. Jogyakarta: A+PLUS BOOKS

Gusmira, S, 2012. Evaluasi Pengunaaan Antihipertensi Konvensional dan Kombinasi Konvensional Bahan Alam pada pasien Hipertensi di Puskesmas Wilayah Depok, Makara, Kesehatan, vol. 16, No. 2. 77-83

Ibrahim, Dan Zakirullah Syafei. 2013. "Perbedaan Nilai Tekanan DArah Lansia Dengan Hipertensi Sebelum dan Sesudah Olahraga Senam pada Lansia". Jurnal Ilmu Keperawatan 
Nugroho, H.W. 2009. Keperawatan Gerontik dan Geriantik. Kedokteran. EGC. Jakarta.

Irmaya Sari (2019) "Pengaruh Pemberian Air Rebusan Daun Sambung Nyawa (gynura procumbens) Terhadap Tekanan Darah Pada Lansia Yang Mengalami Hipertensi di Puskesmas Lubuk Jambi"

Junaidi, I.2010. Hipertensi pengenalan, pencegahan, dan pengobatan. Jakarta : PT Bhuana Ilmu Populer

Kementrian Kesehatan Republik Indonesia. (2017, 2019).

Maryam, dkk. 2008. Mengenal Usia Lanjut dan keperawatannya. Jakarta: Salemba Medika

Nasrullah, D. (2016). Buku Ajar Ilmu Keperawatan Gerontik Dengan Pendekatan Asuhan Keperawatan Nanda Nic Noc. Jilid 1. Jakarta: Salemba Medika.

Nur Syaroh (2019) dengan judul "Pengaruh Rebusan Daun Sambung Nyawa (Gynura Procumbens) Terhadap Tekanan Darah Pada Lansia Hipertensi Di Desa Borobudur Tahun 2019"

Nurarif .A.H. dan Kusuma. H. (2015). Aplikasi Asuhan Keperawatan Berdasarkan Diagnosa Medis \& NANDA NIC-NOC. Jogjakarta: MediAction.

Parsudi Imam A, Martono Hadi, Bachtiar Ari. (1992). Hipertensi Penatalaksanaan Secara Menyeluruh. Semarang : Badan Penerbit Undip. b. Rokhaeni Heni, Purnamasari Elly, Rahayoe Anna Ulfah. (2001). Parwati, (2018). Asuhan Keperawatan Keluarga Dengan Masalah Utama Hipertensi Pada Tn. $R$ Di Wilayah Kerja Puskesmas Mergangsan Kota Yogyakarta. Jurnal. Yogyakarta: Politeknik Kesehatan Kementrian Kesehatan.

Ridha Hidayat (2020) dengan judul "Pengaruh Pemberian Daun Sambung Nyawa terhadap Penurunan Tekanan
Darah Pada Penderita Hipertensi di Desa Kuapan Wilayah Kerja Puskesmas Tambang"

Rufaida, (2018). Terapi Komplementer. Mojokerto: Stikes Majapahit Mojokerto.

Siti, A., Joyeti, D., Fathimah, F., (2019). Pengaruh Larutan Madu terhadap Tekanan Darah Lanjut Usia Hipertensi, Jurnal. Ngawi: Program Studi Gizi, Universitas Darussalam Gontor.

Siwi., Rin, A., (2018). Filsafat Ilmu. ResearchGate. Semarang: Fakultas Sains Dan Matematika Universitas Diponegoro 
